\title{
DESCARTE IRREGULAR DE ESTOFADOS NA CIDADE DE MARINGÁ - PR
}

Camila Alcântara Pereira

Centro Universitário Unicesumar

camilaalcantara_@hotmail.com

Larissa Siqueira Camargo

Centro Universitário Unicesumar

larissa.camargo@unicesumar.edu.br

Carla Prado Vieira

Centro Universitário Unicesumar

carla.vieira@unicesumar.edu.br

Resumo: O descarte inadequado de estofados vem se tornando cada vez mais comum no dia-a-dia da população brasileira o que não é diferente na cidade de Maringá-PR. Diante desde ato decorrente percebe-se alguns problemas ocasionados que fomenta riscos à população. Nota que aos sofás ficarem expostos em ruas, calçadas e terrenos baldios pode ocorrer o acúmulo de água influenciando na proliferação de mosquitos da dengue, além de possibilitar esconderijos para outros animais, ocasionar poluição a meio urbano, atrapalhar na transição de pedestres e veículos, entre outros transtornos. Baseado nisto o presente projeto de pesquisa tem como objetivo avaliar as causas principais desta prática com o intuito de descobrir as dificuldades encontradas pela população em fazer um descarte correto, tendo em vista, prevê respostas como: dificuldades em doar estes objetos, transportar ou, até mesmo, da falta de conhecimento a respeito dos locais de descarte disponibilizados pela prefeitura da cidade. Para tanto, a metodologia aplicada será revisão bibliográfica, coleta de dados realizada a partir de registros fotográficos, desenvolvimento de relatórios e entrevistas. Para que, através deste estudo seja possível propor medidas que solucione, por diversos ângulos alguns destes diferentes problemas apontados sobre o descarte de estofados no meio urbano.

Palavras-chave: Sofás, lixo urbano, meio ambiente 